\title{
IMPLEMENTASI MODEL PAIR CHECK TERHADAP KEMAMPUAN KOGNITIF PADA KONSEP PENCEMARAN LINGKUNGAN
}

\author{
Liska Berlian ${ }^{1}$, Lukman Nulhakim², Vivi Wahyuningsih ${ }^{3}$, \\ 1,2,3 Program Studi Pendidikan IPA, FKIP, Universitas Sultan Ageng Tirtayasa, Serang, Banten \\ e-mail: ${ }^{1}$ liska.berlian@untirta.ac.id, ${ }^{2}$ lukman.nulhakim@untirta.ac.id, \\ 3 wahyuningsihvivi@gmail.com
}

\begin{abstract}
ABSTRAK
Penelitian ini bertujuan untuk mengetahui pengaruh model pembelajaran Pair Check terhadap kemampuan kognitif siswa pada konsep pencemaran lingkungan. Penelitian ini merupakan penelitian quasy exsperiment dengan menggunakan desain penelitian nonequivalent control group design. Populasi dalam penelitian ini adalah seluruh siswa kelas VII SMPN 14 Kota Serang tahun pelajaran 2019/2020. Sampel penelitian ini terdiri dari dua kelas, yaitu kelas VII B sebagai kelas eksperimen dan kelas VII C sebagai kelas kontrol. Teknik pengumpulan data menggunakan tes objektif pilihan ganda. Persentase nilai rata-rata pre-test sebesar $61,5 \%$ dan post-test kelas eksperimen sebesar 79,8\% berada dalam kategori baik, sedangkan persentase nilai rata-rata pre-test kelas kontrol sebesar $51,6 \%$ dan post-test sebesar $67,7 \%$ berada dalam kategori cukup. Hasil uji hipotesis pengaruh model pembelajaran Pair Check terhadap kemampuan kognitif siswa pada konsep pencemaran lingkungan menggunakan uji t pada taraf signifikansi $\alpha=0,05$ diperoleh nilai 0,000 . Berdasarkan hasil penelitian, dapat disimpulkan bahwa terdapat pengaruh model pembelajaran Pair Check terhadap kemampuan kognitif siswa pada konsep pencemaran lingkungan.
\end{abstract}

Kata Kunci : Pair Check, Kognitif, Pencemaran Lingkungan

\begin{abstract}
The aim of this study is to know the effect of Pair Check learning models on students' cognitive abilities on the concept of environmental pollution. This research is a quasyexperimental research using the nonequivalent control group design. The population in this study were all students at grade VII of SMPN 14 Serang City in the academic year 2019/2020. The research sample consisted of two classes, namely class VII B as an experimental class and class VII C as a control class. Data collection techniques in this study used multiple choice objective tests. The percentage of the average pre-test score of $61.5 \%$ and the experimental class post-test of $79.8 \%$ were in the good category, while the percentage of the pre-test mean value of the control class was $51.6 \%$ and the post-test amounted to $67.7 \%$ are in the moderate category. The result of hypothesis test about the influence of Pair Check learning models on the cognitive abilities of students on the concept of environmental pollution using the t test at the significance level $\alpha=0.05$, obtained a value of 0,000. Based on the results of the study, it can be concluded that there is an effect of the Pair Check learning model on students' cognitive abilities on the concept of environmental pollution.
\end{abstract}

Keywords: Pair Check, Cognitive, Environmental Pollution 


\section{PENDAHULUAN}

Proses pembelajaran merupakan inti dari proses pendidikan formal di sekolah yang di dalamnya terjadi interaksi antara berbagai komponen seperti guru, siswa, dan materi pembelajaran (Sumiati \& Asra, 2009). Pembelajaran sains adalah upaya untuk membelajarkan siswa. Husamah (2013) menjelaskan bahwa dalam proses pembelajaran terdapat kegiatan seperti memilih, menetapkan serta, mengembangkan suatu model pembelajaran untuk mencapai hasil pembelajaran yang diinginkan, serta didasarkan pada kondisi pembelajaran. Belajar adalah proses interaksi seseorang dengan lingkungannya yang menimbulkan perubahan tingkah laku. Belajar yang aktif ditandai dengan terjadinya proses belajar dalam diri siswa.

Proses belajar yang aktif sangat diperlukan dalam pembelajaran IPA agar siswa mampu meningkatkan hasil belajar dan mengaplikasikan konsep dalam kehidupan nyata di masyarakat (Hamalik, 2009). Berkaitan dengan penelitian sebelumnya, tinggi atau rendahnya kualitas hasil belajar siswa disebabkan oleh dua faktor, yaitu faktor internal dan faktor eksternal. Beberapa contoh faktor internal dan faktor eksternal yang dapat mempengaruhi proses belajar dan hasil yang diinternalisasi antara lain; minat, sikap terhadap belajar, motivasi untuk belajar, serta konsentrasi belajar, sedangkan untuk faktor eksternal seperti : guru sebagai pelatih belajar, infrastruktur dan fasilitas belajar, kebijakan penilaian, lingkungan siswa di sekolah dan di rumah serta kurikulum sekolah (Maesaroh, 2013).

Hasil belajar siswa dapat menghasilkan tiga pembentuk kemampuan, yaitu kemampuan kognitif, afektif dan psikomotorik. Kemampuan kognitif berkenaan dengan pengetahuan siswa, kemampuan afektif berkenaan dengan sikap siswa, dan kemampuan psikomotorik berkenaan dengan keterampilan atau kemampuan bertindak setelah siswa menerima pengalaman belajar tertentu (Sudjana, 2009). Terkait dengan pendapat di atas, bahwa kemampuan kognitif mampu membuat siswa paham dengan konsepkonsep materi pembelajaran, sedangkan kemampuan afektif akan mengubah siswa ke arah yang lebih baik dalam pembelajaran, dan kemampuan psikomotorik akan menunjang keahlian siswa karena terlibat langsung dalam proses pembelajarannya (Rahayu dkk, 2011).

Berdasarkan hasil observasi di Sekolah, diketahui bahwa kemampuan kognitif siswa masih tergolong rendah. Hal itu dilihat dari hasil nilai ulangan harian dan hasil Penilaian Akhir Semester (PAS) siswa yang masih di bawah Kriteria Ketuntasan Minimum (KKM) yang telah ditetapkan. Hal tersebut disebabkan oleh rendahnya tingkat belajar siswa pada saat proses pembelajaran. Pada saat proses pembelajarannya kebanyakan siswa masih sering tidak fokus dalam memperhatikan guru pada saat penyampaian materi pembelajaran.

Model pembelajaran sangat erat kaitannya dengan gaya belajar siswa dan gaya mengajar guru. Melalui model pembelajaran, guru dapat membantu siswa untuk mendapatkan informasi, keterampilan, cara berpikir dan mengekspresikan idenya. Guru harus dapat memilih model pembelajaran yang sesuai dengan materi yang akan disampaikan sehingga siswa mempunyai minat yang tinggi dalam mengikuti pembelajaran. Berdasarkan hal tersebut, pemilihan model pembelajaran oleh guru berperan penting dalam meningkatkan hasil belajar siswa, baik dari aspek kognitif, afektif maupun 
psikomotoriknya. Maka dari itu, peneliti menggunakan model pembelajaran kooperatif tipe Pair Check sebagai pertimbangan variasi model pembelajaran. Model pembelajaran kooperatif tipe Pair Check merupakan metode pembelajaran berkelompok antar dua orang atau berpasangan yang dipopulerkan oleh Spencer Kagan pada tahun 1990. Pembagian kelompok siswa secara berpasangan menunjukkan pencapaian yang jauh lebih besar dalam bidang ilmu pengetahuan daripada kelompok yang terdiri atas empat atau lima orang (Slavin, 2010). Menurut Nusantari et al (2008), model pembelajaran Pair Check dapat meningkatkan kerja sama antar siswa dalam kegiatan memecahkan suatu permasalahan dan dapat mengajarkan kepada siswa untuk saling menghargai dan saling membantu terhadap siswa yang kurang aktif. Model ini menerapkan pembelajaran kooperatif yang menuntut kemandirian dan kemampuan siswa dalam menyelesaikan persoalan. Model ini juga melatih tanggung jawab sosial siswa, kerja sama dan kemampuan memberi penilaian (Huda, 2013). Berdasarkan penelitian sebelumnya, model pembelajaran Pair Check ini dapat meningkatkan kemampuan kognitif siswa dibandingkan dengan kelas yang masih menggunakan model dan metode konvensional. Terlihat adanya perbedaan nilai diantara kedua kelas tersebut (Lisdarsih, 2016).

\section{METODE PENELITIAN}

Metode kuasi eksperimen digunakan dalam penelitian ini. Desain penelitian yang digunakan nonequivalent control group design yang melibatkan dua kelompok yaitu kelas eksperimen dan kelas kontrol. Dalam penelitian ini peneliti menyelidiki pengaruh model pembelajaran Pair Check terhadap kemampuan kognitif siswa pada konsep Pencemaran Lingkungan.

Subyek penelitian dalam penelitian ini terdiri dari 72 siswa dan penelitian ini dilakukan pada bulan Juli 2019 di SMPN 14 kota Serang, Banten. Instrumen yang digunakan dalam penelitian ini adalah instrumen tes pilihan ganda sebanyak 20 butir soal yang telah divalidasi dan layak untuk digunakan berdasarkan hasil expert judgment dan lembar observasi keterlaksanaan pembelajaran.

\section{HASIL DAN PEMBAHASAN}

Penelitian ini membahas kemampuan kognitif siswa melalui model pembelajaran Pair Check. Sampel yang digunakan dalam penelitian ini adalah kelas VII B sebagai kelas eksperimen yang diterapkan model pembelajaran Pair Check dan kelas VII C sebagai kelas kontrol yang diterapkan model pembelajaran $S T A D$, masing-masing kelas tersebut berjumlah 36 siswa. Penelitian ini dilakukan pada mata pelajaran IPA materi Pencemaran Lingkungan. Instrumen penelitian ini berupa tes kemampuan kognitif siswa seperti pretest dan posttest. Penilaian kemampuan kognitif siswa pada penelitian ini diukur menggunakan tes objektif berupa pilihan ganda sebanyak 20 butir soal. Hasil uji statistik dapat dilihat pada Tabel 1 berikut :

Tabel 1. Hasil Uji Statistik Kemampuan Kognitif Siswa

\begin{tabular}{llll}
\hline \multirow{2}{*}{ Parameter } & $\begin{array}{l}\text { Nilai } \\
\text { Signifikansi } \\
\text { Statistik Per }\end{array}$ & Keterangan & \\
& Kelas & & \\
& Eksperimen & Kontrol & Keterangan \\
Uji & 0,20 & 0,076 & Berdistribusi
\end{tabular}




\begin{tabular}{lcl} 
Normalitas & & \multicolumn{1}{c}{ Normal } \\
Uji & \multicolumn{2}{c}{ Homogen } \\
Homogenitas & 0,156 & $<0,05$ maka $\mathrm{H}_{1}$ diterima
\end{tabular}

Untuk mengetahui apakah model pembelajaran Pair Check berpengaruh terhadap kemampuan kognitif siswa, maka dilakukan uji statistik penelitian terlebih dahulu. Data nilai rata-rata kemampuan kognitif siswa dilakukan dengan menggunakan uji prasyarat penelitian, yaitu menggunakan uji normalitas dan uji homogenitas. Setelah itu dilakukan uji statistik penelitian dengan menggunakan uji T. Berdasarkan tabel di atas diperoleh data nilai posttest kemampuan kognitif untuk kedua kelas (eksperimen dan kontrol) berdistribusi normal dan homogen. Berdasarkan hasil tersebut, maka hipotesis yang menyatakan adanya pengaruh model pembelajaran Pair Check terhadap kemampuan kognitif siswa pada konsep Pencemaran Lingkungan" dapat diterima. Hasil pengolahan data kemampuan kognitif siswa tertera pada Gambar 1.

\section{Persentase Hasil Kemampuan Kognitif Siswa pada Konsep Pencemaran Lingkungan}

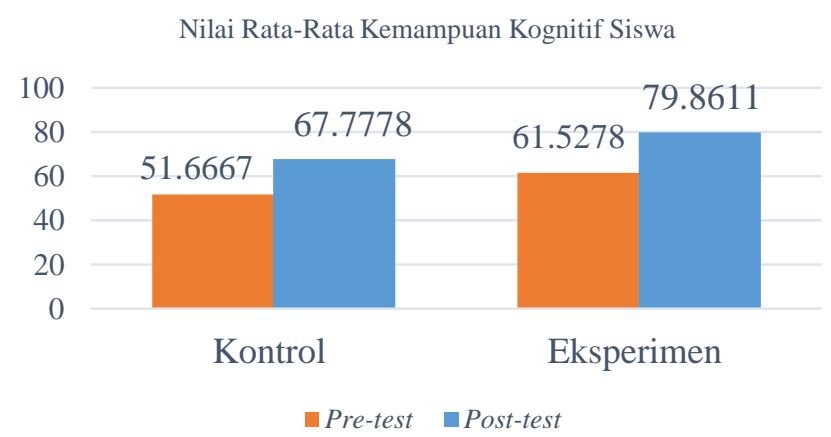

\section{Gambar 1. Nilai rata-rata pretest dan posttest Kemampuan Kognitif Siswa}

Gambar 1. menunjukkan nilai rata-rata pretest siswa pada kelas kontrol dengan menggunakan model STAD sebesar 51,6667 dan kelas eksperimen sebesar 61,5278. Kedua kelas dalam penelitian ini baik kelas kontrol maupun kelas eksperimen sama-sama berada pada kategori kurang, sedangkan untuk nilai rata-rata posttest pada kelas eksperimen dengan menggunakan model pembelajaran Pair Check sebesar 79,8611 lebih besar daripada nilai rata-rata posttest siswa pada kelas kontrol dengan menggunakan model STAD yaitu sebesar 67,7778. Setelah diterapkan model pembelajaran Pair Check, nilai siswa pada materi Pencemaran Lingkungan menjadi lebih baik dari sebelumnya. Perbedaan nilai rata-rata antara kelas eksperimen dan kelas kontrol disebabkan oleh adanya perlakuan yang berbeda (Nazir, 2009). Hal ini sejalan dengan penelitian Yantiani (2013) yang menunjukkan perolehan rata-rata nilai kelas eksperimen berbeda dibandingkan dengan kelas kontrol disebabkan karena kelas eksperimen mendapatkan perlakuan berupa model pembelajaran Pair Check. Saat proses pembelajaran di kelas eksperimen, siswa belajar dengan lebih leluasa untuk berpendapat serta menggali potensinya.

Hasil penelitian (Gambar 1) yang menunjukkan nilai pretest dan posttest kelas eksperimen lebih besar jika dibandingkan dengan kelas kontrol membuktikan bahwa model pembelajaran Pair Check mendapatkan hasil 
pembelajaran yang lebih baik jika dibandingkan dengan pembelajaran di kelas kontrol. Hal ini juga sejalan dengan hasil penelitian Kuslaila et al (2017)., Sari et al (2015), Wijayanti \& Kusdiyanta (2019), Ahmad (2016), Rahmasari et al (2016). Ditambahkan pula oleh Ermavianti, D., \& Sulistyorini, W. (2016), bahwa model pembelajaran kooperatif tipe Pair Check mampu membangun dan meningkatkan keterampilan bertanya produktif siswa. Hal ini ditandai dengan frekuensi siswa dalam bertanya mengalami peningkatan, dan mampu membaca secara produktif sesuai dengan teks/bacaan yang diberikan oleh guru.

\section{Hasil Analisis Kemampuan Kognitif Siswa Berdasarkan Kategori}

Kemampuan Kognitif Siswa Berdasarkan Kategori

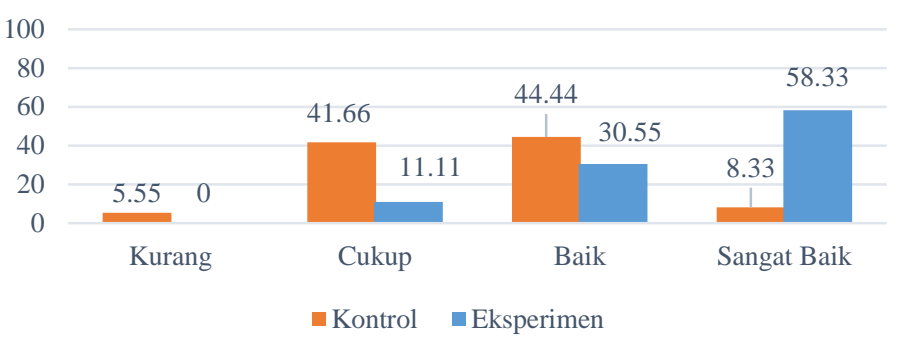

Gambar 2. Kemampuan Kognitif Siswa Berdasarkan Kategori

Berdasarkan Gambar 2. kemampuan kognitif siswa pada kelas eksperimen berada pada kategori cukup sampai sangat baik, sedangkan kemampuan kognitif siswa pada kelas kontrol berada pada kategori kurang sampai sangat baik. Hal ini menunjukkan bahwa kemampuan kognitif siswa pada kelas eksperimen dengan menggunakan model pembelajaran Pair Check lebih baik dibandingkan dengan kemampuan kognitif siswa pada kelas kontrol yang menggunakan model STAD. Kemampuan kognitif siswa kelas eksperimen berdasarkan kategori sangat baik, menunjukkan bahwa siswa pada kelas tersebut benar-benar memperhatikan setiap proses dalam pembelajaran dan memahami materi yang disampaikan. Pada saat proses pembelajaran menggunakan model pembelajaran Pair Check, terdapat sintaks bertukar peran, yaitu siswa bisa menjadi pelatih dan bisa juga menjadi rekan dalam menyelesaikan persoalan dari guru. Selain itu, adanya tutor sebaya dalam model Pair Check menambah wawasan siswa dalam pembelajaran, sehingga siswa dapat bertukar pikiran dalam kegiatan belajarnya. Hal ini merupakan salah satu faktor bahwa perhatian siswa merupakan hal terpenting pada saat proses pembelajaran, sedangkan kemampuan kognitif siswa pada kelas kontrol berada pada kategori kurang, dikarenakan dalam pembelajaran di kelas kontrol yang menggunakan model STAD siswa cenderung mengandalkan siswa yang lain dalam diskusi kelompok. Hal ini disebabkan oleh beberapa faktor diantaranya kemampuan siswa pada saat pembelajaran sangat berbeda-beda sehingga hal tersebut dapat berpengaruh pada hasil belajar siswa tersebut. 


\section{Persentase Rata-rata Hasil Observasi Keterlaksanaan Pembelajaran}

\section{Rata-rata Persentase Hasil \\ Observasi Keterlaksanaan \\ Pembelajaran}

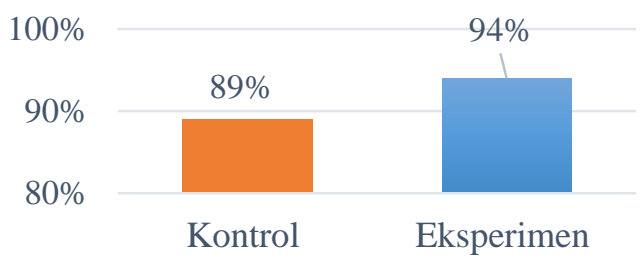

Gambar 3. Persentase Rata-rata Hasil Observasi Keterlaksanaan Pembelajaran

Berdasarkan Gambar 3, hasil lembar observasi dari observer pada saat dilakukan penelitian, menunjukkan bahwa pelaksanaan pembelajaran berjalan dengan sangat baik. Berdasarkan data tersebut, maka dapat disimpulkan bahwa model pembelajaran Pair Check pada pokok bahasan Pencemaran Lingkungan merupakan model yang tepat untuk digunakan. Hal tersebut dikarenakan dari langkah 1 sampai 7 siswa dapat mengikuti semua alur kegiatan pembelajarannya. Proses pembelajaran pada kelas kontrol hanya menggunakan model STAD, sehingga siswa cenderung mengandalkan siswa yang lain dalam proses pembelajarannya dan siswa kurang tertarik untuk mempelajari materi pembelajaran. Pada kemampuan kognitif, data penelitian diukur dengan menggunakan tes berupa soal posttest. Soal tersebut berupa tes objektif dalam bentuk soal pilihan ganda dengan kategori $\mathrm{C} 1$ sampai $\mathrm{C} 4$, persentase hasil kemampuan kognitif siswa disajikan pada Gambar 4.

\section{Persentase Hasil Kemampuan Kognitif Siswa Per Indikator}

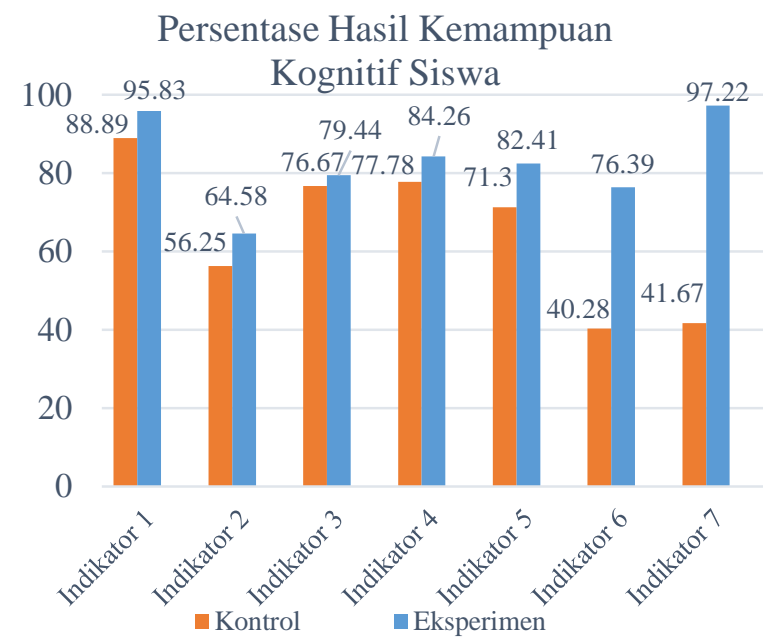

Gambar 4. Persentase Hasil Kemampuan Kognitif Siswa per Indikator 
Berdasarkan Gambar 4. persentase hasil kemampuan kognitif siswa dengan keterangan indikator dijelaskan secara rinci sebagai berikut :

\section{Menguraikan jenis-jenis pencemaran lingkungan}

Terlihat bahwa nilai rata-rata pada masing-masing indikator pembelajaran di kelas eksperimen lebih besar daripada kelas kontrol. Hasil masing-masing skor indikator pembelajaran kelas eksperimen dan kelas kontrol dapat disimpulkan bahwa nilai rata-rata tertinggi indikator pembelajaran pada kemampuan kognitif siswa terdapat pada indikator 1 yaitu menguraikan jenis-jenis pencemaran lingkungan sebesar 95,83\% dan pada kelas kontrol sebesar $88,89 \%$. Karakteristik soal yang mudah pada indikator tersebut dan proses pembelajaran yang berjalan dengan adanya diskusi bersama mengenai pengertian pencemaran di lingkungan yang dikaitkan dengan keadaan di sekeliling dan kehidupan sehari-hari serta pengulangan dalam bentuk pertanyaan kepada siswa yang kemungkinan menjadi faktor pemicu kemampuan siswa dalam indikator tersebut tinggi. Hal ini menunjukkan bahwa sebagian besar siswa dapat memahami dengan baik mengenai pencemaran lingkungan. Peningkatan dari nilai tersebut karena siswa saling membimbing dalam pembelajaran. Adanya langkah dalam bertukar peran memungkinkan untuk siswa yang pasif menjadi lebih aktif dalam proses belajar.

\section{Menguraikan berbagai pencemaran air di lingkungan sekitar}

Untuk kelas eksperimen yang mendapatkan nilai rendah yaitu pada indikator 2 dengan persentase sebesar $64,58 \%$ yang mengaitkan pencemaran lingkungan oleh aktivitas manusia. Persentase indikator ini terendah karena siswa sebagian besar menjawab tidak tepat (salah) dalam hasil akumulasi soal pada indikator tersebut. Hal yang mungkin terjadi adalah karena siswa kurang teliti dalam mengerjakan soal. Pada pembelajarannya, siswa mungkin juga kurang memahami persoalan yang telah didapatkan sehingga nilai yang didapatkan belum maksimal, sementara kelas kontrol nilai rata-rata pada indikator ke 2 adalah $56,25 \%$. Hal ini menunjukkan bahwa siswa pada kelas kontrol kurang memahami pada saat berjalannya diskusi dalam kegiatan pembelajaran.

\section{Menguraikan berbagai pencemaran udara di lingkungan sekitar}

Untuk mencapai indikator tersebut siswa di kelas eksperimen harus bertukar peran pada saat kegiatan pembelajarannya. Adapun proses pembelajaran di kelas kontrol hanya melakukan diskusi dalam kelompok besar. Dapat dilihat bahwa persentase indikator ke 3 pada kelas eksperimen 79,44 \%, sedangkan pada kelas kontrol $76,77 \%$. Hal ini dikarenakan pada kelas ekperimen, siswa melakukan kegiatan dengan cara saling bergantian mengerjakan soal pada proses pembelajarannya sehingga siswa mampu menguraikan pencemaran di lingkungan sekitar. Siswa dalam kelas eksperimen juga saling membantu jika ada kesulitan yang ditemui dalam kelompok, sedangkan pada kelas kontrol hanya berdiskusi kelompok saja dalam proses pembelajarannya, sehingga sebagian siswa ada yang cenderung pasif dalam berdiskusi pada kelompoknya masing-masing. Pada proses pembelajaran di kelas kontrol, kebanyakan siswa hanya mengandalkan siswa yang lain dalam melakukan proses diskusi.

\section{Menguraikan berbagai pencemaran tanah di lingkungan sekitar}

Untuk mencapai indikator ke 4 siswa dalam kelas eksperimen saling memeriksa jawaban dan salah satu teman harus memberi informasi terkait jawaban yang sesuai. Dalam hal ini disebut juga sebagai tutor sebaya yang memberikan wawasan terhadap siswa lain sehingga siswa yang lain sama-sama mengerti dan memahami materi yang diajarkan. Persentase kelas eksperimen sebesar 84,26\%, sedangkan pada kelas kontrol hanya sebesar $77,73 \%$. Hal ini membuktikan bahwa pada kelas kontrol menggunakan model STAD dalam diskusi kelompok besar tidak semua siswa aktif dalam proses pembelajarannya. 


\section{Menganalisis dampak pencemaran air bagi ekosistem}

Untuk mencapai indikator ke 5 dengan menganalisis, pada kelas eksperimen siswa melakukan diskusi berpasangan dalam menelaah gambar yang tertera di LKS lalu siswa mengemukakan pendapatnya terkait peristiwa yang harus dijelaskan pada situasi tersebut. Sementara pada kelas kontrol menggunakan diskusi bersama kelompok besar sehingga ditemukan pada saat pembelajaran berlangsung, masing-masing ada saja siswa yang tidak memperhatikan proses pembelajarannya. Pada kelas eksperimen terdapat persentase sebesar $82,41 \%$ sedangkan kelas kontrol hanya sebesar $71,3 \%$.

\section{Menganalisis dampak pencemaran udara bagi ekosistem}

Untuk mencapai indikator yang ke 6 siswa pada kelas ekperimen melakukan kegiatan evaluasi. Pada saat teman sebangku mengerjakan soal, teman yang menjadi tutor sebaya harus mengecek jawaban teman yang lain sehingga pengetahuan siswa menjadi bertambah dan siswa juga aktif dalam melakukan pembelajaran di kelas. Pada saat proses pembelajaran berlangsung di kelas kontrol ditemukan siswa tidak semuanya aktif, karena dalam diskusi kelompok besar ada saja siswa yang tidak fokus dalam belajar. Hal ini menyebabkan persentase yang diperoleh pada kelas eksperimen sebesar $76,39 \%$, sedangkan pada kelas kontrol sebesar 40,28\%.

\section{Menganalisis dampak pencemaran tanah bagi ekosistem}

Untuk mencapai indikator yang terakhir yaitu menganalisis dampak pencemaran tanah, siswa diberi arahan oleh guru untuk melihat keadaan lingkungan sekitar saat tanah tercemar oleh bahan kimia maupun limbah rumah tangga serta hal-hal apa saja yang akan ditimbulkan dari hal tersebut. Lalu siswa diberi waktu untuk menyimpulkan bersama dalam kegiatan pembelajarannya. Pada kelas kontrol, siswa menyimpulkannya melalui presentasi kelompok, setiap siswa harus mengemukakan pendapat yang mereka ketahui terkait dengan materi pencemaran lingkungan tersebut. Maka diperoleh hasil persentase sebesar $97,22 \%$ pada kelas eksperimen dan $41,67 \%$ pada kelas kontrolnya. Siswa pada kelas eksperimen melakukan kegiatan pembelajaran dengan adanya tutor sebaya, sehingga siswa yang satu dengan yang lainnya saling membantu dan memiliki tanggung jawab masingmasing untuk menyelesaikan permasalahan tersebut. Siswa pada kelas kontrol lebih sering mengandalkan siswa lain dalam jalannya diskusi, sehingga pada saat presentasi, siswa yang tidak berdiskusi dengan baik tidak mengerti permasalahan yang diberikan oleh guru. Berdasarkan penelitian yang dilakukan, dapat disimpulkan bahwa penerapan model pembelajaran Pair Check ini melatih kerja sama antarsiswa sehingga siswa yang cenderung pasif akan mengikuti proses pembelajaran dengan baik. Sejalan dengan penelitian yang dilakukan oleh Lestari $d k k$ (2012), bahwa model pembelajaran Pair Check dapat meningkatkan kerja sama dan komunikasi yang baik antarsiswa sehingga keterlibatan siswa pada saat proses pembelajaran berlangsung dapat menimbulkan hasil yang maksimal sesuai dengan yang diharapkan, dan siswa lebih dapat memperoleh banyak kesempatan untuk menambah tingkat pemahaman mereka terhadap suatu bahasan materi tertentu. Sejalan dengan penelitian yang dilakukan oleh Saputra pada tahun 2018 yang menunjukkan bahwa setelah dilakukan perlakuan yang berbeda pada kedua kelas, nilai rata-rata pada kelas yang menggunakan model Pair Check lebih baik dibandingkan kelas kontrol.

\section{Hasil Analisis N-Gain Kemampuan Kognitif Siswa}

Nilai rata-rata posttest kelas eksperimen lebih besar dibandingkan dengan kelas kontrol. Perbedaan tersebut diperkuat oleh nilai indeks gain yang diperoleh pada Gambar 4.5. Nilai Indeks Gain berfungsi untuk melihat kualitas peningkatan kemampuan kognitif kelas 
kontrol dan kelas eksperimen. Terlihat bahwa nilai rata-rata dari kelas eksperimen dan kelas kontrol memiliki perbedaan. Pada kelas eksperimen diperoleh N-Gain sebesar 0,4454, sedangkan pada kelas kontrol diperoleh N-Gain sebesar 0,3072.

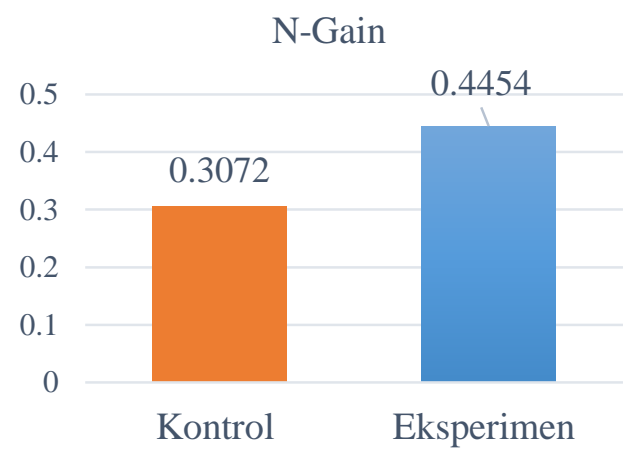

\section{Gambar 5. Nilai Indeks Gain pada Kelas Eksperimen dan Kontrol}

Dapat dilihat pada gambar di atas, bahwa nilai rata-rata posttest kelas eksperimen lebih besar dibandingkan dengan kelas kontrol. Perbedaan tersebut diperkuat oleh nilai indeks gain yang diperoleh pada Gambar 1.5 di atas. Nilai indeks Gain berfungsi untuk melihat kualitas peningkatan kemampuan kognitif kelas kontrol dan kelas eksperimen (Arifin, 2011).

Terlihat bahwa nilai rata-rata dari kelas eksperimen dan kelas kontrol memiliki perbedaan. Pada kelas eksperimen diperoleh N-Gain sebesar 0,4454, sedangkan pada kelas kontrol diperoleh $\mathrm{N}$ Gain sebesar 0,3072. Berdasarkan Gambar 5, maka diketahui bahwa nilai indeks Gain antara kelas kontrol dan kelas eksperimen terdapat perbedaan, yaitu pada kelas kontrol sebesar 0,3072, sedangkan pada kelas eksperimen sebesar 0,4454. Peningkatan nilai pretest ke nilai posttest pada kelas kontrol dan kelas eksperimen berada dalam kategori yang sama, yaitu dalam kategori sedang. Namun, jika dilihat dari nilainya, untuk kelas eksperimen mengalami peningkatan yang lebih besar dibandingkan dengan kelas kontrol. Hal ini sejalan dengan penelitian Hidayah $d k k$ (2018) bahwa model pembelajaran Pair Check memiliki pengaruh positif terhadap hasil belajar siswa karena model pembelajaran ini membuat siswa menjadi lebih aktif dan mampu bekerja secara mandiri dalam menyelesaikan masalah. Hal tersebut terbukti setelah siswa melakukan kegiatan pembelajaran dengan menggunakan model pembelajaran Pair Check bahwa hasil belajar siswa menjadi lebih baik. Berbeda dengan siswa yang di dalam proses pembelajarannya dilakukan dengan model STAD atau model yang digunakan guru dalam mengajar seharihari, siswa yang diajarkan dengan model ini kurang aktif karena dibagi dalam kelompok besar dan masih ada saja yang tidak bisa diajak kerja sama karena merasa sudah ada siswa lain yang menyelesaikan persoalan yang diberikan oleh guru. Hal ini dapat dikatakan bahwa sikap kerja sama antar siswa dapat mempengaruhi berlangsungnya proses pembelajaran, karena jika kerja sama antarsiswa hanya mengandalkan siswa yang lain maka pembelajaran pun tidak akan berlangsung seperti yang diharapkan. Pelaksanaan pembelajaran dengan model Pair Check pada akhirnya mempengaruhi kemampuan kognitif siswa. Hasil tersebut sesuai dengan penelitian yang dilakukan oleh Utomo et al (2016) yang menunjukkan bahwa dengan menggunakan model pembelajaran Pair Check dapat meningkatkan hasil belajar siswa. 


\section{KESIMPULAN}

Berdasarkan hasil penelitian, dapat disimpulkan bahwa terdapat pengaruh model pembelajaran Pair Check terhadap kemampuan kognitif siswa pada konsep pencemaran lingkungan dengan persentase nilai rata-rata pre-test sebesar $61,5 \%$ dan

\section{DAFTAR PUSTAKA}

Ahmad, F. (2016). Penerapan Model Pembelajaran Kooperatif Tipe Pair Checks dalam Meningkatkan Motivasi dan Hasil Belajar IPA Tepadu Siswa Kelas VIIIA SMP Negeri 1 Tabulahan Kab. Mamasa. Jurnal Sainsmat. Vol. V, No. 2, Halaman 137-142.

Arifin, Z. (2011). Metode Penelitian Kualitatif, Kuantitatif, dan $R \& D$. Bandung: Alfabeta.

Ermavianti, D., \& Sulistyorini, W. (2016). Model Pembelajaran Kooperatif Tipe Pair Check untuk Membangun Keterampilan Bertanya Produktif Siswa. Jurnal Pendidikan Teknologi dan Kejuruan. Vol. 23, No. 1, pp. 1-15.

Hamalik, O. (2009). Proses Belajar Mengajar. Jakarta: PT. Bumi Aksara

Hidayah, N.F. Syaiful, \& Ekwandari, .Y.S. 2018. Pengaruh Model Pembelajaran Pair Check Terhadap Hasil Belajar Kognitif Siswa Kelas X IIS. Jurnal Kependidikan Unila.

Huda, M. (2013). Cooperative Learning. Yogyakarta: Pustaka Pelajar.

Husamah. (2013). Desain Pembelajaran. Jakarta: Prestasi Pustaka.

Kuslaila, M., E.F. Ningsih., \& W. Kusumaningtyas. (2017). Eksperimentasi Model Pembelajaran Pair Checks pada Materi Pokok Segitiga Ditinjau dari Gaya Belajar Peserta Didik. Jurnal Ilmiah post-test kelas eksperimen sebesar 79,8\% berada dalam kategori baik, sedangkan persentase nilai rata-rata pre-test kelas kontrol sebesar $51,6 \%$ dan post-test sebesar $67,7 \%$ berada dalam kategori cukup.

Pendidikan Matematika. Vol. 2, No. 2, pp 110-115.

Lestari R, \& S. Linuwih S. 2012. Penerapan Model Pembelajaran Kooperatif Tipe Pair Checks Pemecahan Masalah untuk Meningkatkan Social Skill Siswa. Jurnal Pendidikan Fisika Indonesia. Vol. 8, pp. 190-194.

Lisdarsih, D.W, Sugiyono, \& Halidjah, S. (2016). Pengaruh Model Pair Check Terhadap Hasil Belajar Ilmu Pengetahuan Sosial Kelas IV. Jurnal Pendidikan dan Pembelajaran.

Maesaroh, S. (2013). Peranan Metode Pembelajaran terhadap Minat dan Prestasi Belajar Pendidikan Agama Islam. Jurnal Kependidikan. Vol.1, No.1.

Nazir, M. (2009). Metode Penelitian. Jakarta: Ghalian Indonesia.

Nusantari, Elya, Dukalang, Ravika, \& Lamuhu, Listian. 2008. Peningkatan Keterampilan Belajar Biologi melalui Model Kooperatif Learning Tipe Pair Check Siswa Kelas 2 SMPN 2 Gorontalo. Jurnal Pendidikan dan Pembelajaran. Vol. 15, No. 1.

Rahayu E, Susanto, \& Yulianti. 2011. Pembelajaran Sains dengan Keterampilan Proses untuk Meningkatkan Hasil Belajar Kemampuan Berpikir Kreatif Siswa. 
Jurnal Pendidikan Fisika Indonesia:

Vol. 7, pp. 106-110

Rahmasari, L.L., Wahyudi \& T.S. Susiani. (2017). Penerapan Model Kooperatif Tipe Pair Check dengan Media Konkret dalam Peningkatan Pembelajaran Matematika Tentang Pecahan pada Siswa Kelas IV SD Negeri 1 Jlegiwinangun Tahun Ajaran 2015/2016. Kalam Cendekia, Vol. 4, No. 6.1, pp. $686-691$

Saputra Y.D. (2018). Pengaruh Model Pembelajaran Pair Check Terhadap Hasil Belajar Akuntansi Siswa Kelas XI-2 AP SMK Bina Satria Tahun Ajaran 2017/2018. Skripsi Universitas Muhammadiyah Sumatera Utara Medan.

Sari, G.P., \& R.R. Herkulana. (2015). Efektivitas Model Pembelajaran Pair Check terhadap Keterampilan Siswa pada Mata Pelajaran Akuntansi di SMKN. Jurnal Pendidikan dan Pembelajaran Khatulistiwa. Vol 4, No 9.

Slavin, R. E. (2010). Cooperative Learning Applying Contact Theory in
Desegiated Schools. Journal of Social Issues. Vol. 41, No. 3, pp 45-62.

Sudjana, N. (2009). Penilaian Hasil Proses Mengajar. Bandung: Remaja Rosdakarya.

Sumiati \& Asra. (2009). Metode Pembelajaran. Bandung: CV Wacana Prima.

Utomo, E.S. \& Rahman, F. 2016. Pengaruh Model Pembelajaran Kooperatif Tipe Pair Check Terhadap Hasil Belajar Siswa. Jurnal Pendidikan Matematika UNY.

Wijayanti, A \& A. Kusdiyanta. (2019). Peningkatan Keterampilan Kooperatif Melalui Pair Check Berbantuan Mind Mapping. Formatif: Jurnal Ilmiah Pendidikan MIPA. Vol. 9, No. 3, pp. 257-266.

Yantiani N.M, Wiarta I.W, \& Putra M. (2013). Pembelajaran Kooperatif Berpengaruh Terhadap Hasil Belajar Materi Bangun Ruang dan Bangun Datar Siswa Kelas IV Semarapura. Jurnal Matematika Universitas Pendidikan Ganesha Sigajara. 